\title{
Virus rejection with two model human enteric viruses in membrane bioreactor system
}

\author{
ZHENG Xiang ${ }^{1,2 \dagger} \&$ LIU JunXin ${ }^{1 \dagger}$ \\ ${ }^{1}$ Research Center for Eco-Environmental Sciences, Chinese Academy of Sciences, Beijing 100085, China; \\ ${ }^{2}$ School of Environment \& Natural Resources, Renmin University of China, Beijing 100872, China
}

A membrane bioreactor (MBR) with gravity drain was tested for virus rejection with two coliphages, T4 and $\mathrm{f2}$, which were used as surrogates for human enteric viruses. Virus rejection was investigated by PVDF and PP membrane modules, with the pore sizes of 0.22 and $0.1 \mu \mathrm{m}$, respectively. In tap water system, $2.1 \mathrm{lg}$ rejection of coliphage T4 could be achieved by PVDF membrane compared with complete rejection by PP membrane, while for coliphage $\mathrm{f} 2$ with smaller diameter, $0.3-0.5 \mathrm{lg}$ rejection of the influent virus was removed by the two membranes. In domestic wastewater system, cake layer and gel layer on the membrane surface changed the cut-off size of the membrane so that there was no significant difference between PP and PVDF for each coliphage. The removal ratios of coliphage T4 and $\mathrm{f} 2$ in the MBR were more than 5.5 and $3.0 \mathrm{lg}$, respectively. Compared with $5.5 \mathrm{lg}$ removal for virus T4 in the MBR system, only $2.1 \mathrm{lg}(96.8 \%-99.9 \%)$ removal rate was observed in the conventional activated sludge system with the influent virus concentration fluctuating from 1830 to $57000 \mathrm{PFU} / \mathrm{mL}$. Only $0.8 \%-22 \%$ virus removal was the effect of adsorption to activated sludge, which showed a decreasing tendency with the retention time, while $75 \%-98 \%$ was the effect of virus inactivation by microbial activity. It indicated that the major mechanism of virus removal was not the transfer of viruses from the water phase to the sludge phase but inactivation in the biological treatment process.

MBR, model virus, enteric virus, inactivation

\section{Introduction}

Wastewaters derived from livestock (cattle, dairy, swine, poultry, aquaculture, or any other farm-reared animals), slaughterhouses, and especially from hospitals, may contain a wide variety of microbial pathogens and viruses. These pollutants often enter surface waters from diffuse or non-point sources associated with surface runoff and from point sources typically associated with concentrated farming activities, such as the production of livestock. However, most discharge guidelines regulate bacterial indicators, but not viral indicators, let alone specific pathogens. For example, the existing discharge standard for hospital effluents lays emphasis on bacteriological indicators, such as the number of coliform groups, pathogenic enterobacteria, mycobacterium tuberculosis, etc. As for the behavior of viruses, the re- lated information is very limited. Proper treatment before being discharged into receiving water bodies has become of increasing importance since the worldwide outbreak of SARS and Avian Influenza Virus in recently years $^{[1-4]}$.

Enteric viruses have been found in drinking water, surface water, wastewater and groundwater. Conventional wastewater treatment technology cannot completely remove or inactivate enteric viruses. Recently, membrane bioreactor (MBR) has received increasing

Received September 20, 2006; accepted October 26, 2006

doi: 10.1007/s11426-007-0047-3

†Corresponding author (email: zhengxiang7825@hotmail.com, jxliu@mail.rcees. ac.cn)

Supported by the National Natural Science Foundation of China (Grant No. 50538090), the Opening Foundation of State Key Laboratory of Environmental Aquatic Chemistry Grant (No. 200601) and the Foundation of Renmin University of China (Grant No. 30206.201.301) 
attention in the past two decades as advanced wastewater treatment alternatives ${ }^{[3-5]}$. MBR is a modification of the activated sludge process in which separation of solids is achieved without the requirement of a secondary clarifier. Instead, that this function is carried out by a membrane, which retains the particulate phase within the reactor and allows the treated clarified effluent to the next process. Rejections of membrane include biological and non-biological colloids and macromolecules, resulting in an effluent free from pathogenic microorganisms $^{[5]}$. In previous studies, MBR showed extreme efficiency in the removal of bacteria ${ }^{[5-8]}$. However, there is relatively little information about the rejection of viruses, which is becoming an important issue in recent years $^{[8-10]}$.

Our objectives of this research were to evaluate the effects of membrane pore sizes on virus rejection in the tap water and activated sludge systems. In addition, the roles of virus inactivation by microbial activity and virus adsorption by activated sludge were evaluated in a biological treatment system. Two viruses with bacterial hosts (coliphages), T4 and $\mathrm{f} 2$, were used in this research as surrogates for human enteroviruses to assess the MBR's efficiency in virus removal ${ }^{[11-13]}$. It is mainly because of the following: (1) The coliphage $\mathrm{f} 2$ is similar to Poliovirus, Coxsackievirus, Echovirus, Norwalk agent and Hepatitis A virus, while T4 is similar to Adenovirus, Reovirus and Rotavirus (Table 1); (2) it is non-pathogenic to humans and can be seeded with a high concentration in tracer experiments; (3) they have good survival characteristics, and can represent the actual removal mechanism occurring in sewage treatment work; and (4) the assay is simple and rapid.

\section{Materials and methods}

\subsection{System description}

An MBR with gravity drain was used to treat municipal wastewaters in this study (Figure 1). The bioreactor is an airlift reactor, and two membrane modules with the mean pore sizes of 0.22 and $0.1 \mu \mathrm{m}$ were put in its downside, respectively. The bioreactor had an effective volume of $12 \mathrm{~L}$, and the membrane flux was driven by the pressure-head between the liquid levels in the bioreactor and the effluent pipe $(8.5 \mathrm{kPa})$. Compressed air is supplied from the bottom of the module, and the membrane surface can be cleaned by air turbulence. The MBR was continuously operated by gravity drain under a given pressure head.

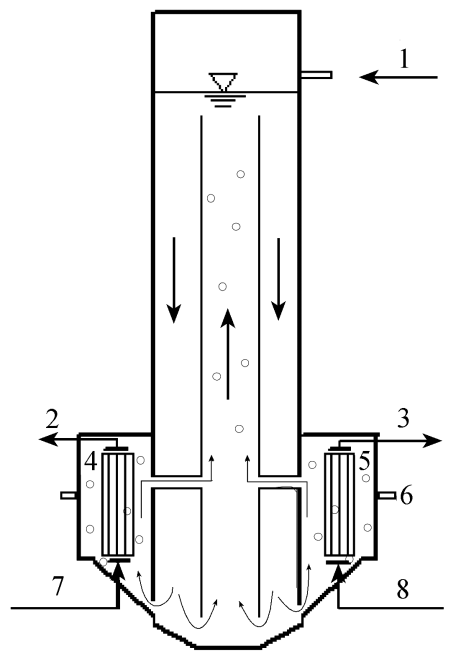

Figure 1 The schematic diagram of the MBR. 1, Influent; 2,3, effluent; 4 , module $(0.1 \mu \mathrm{m}) ; 5$, module $(0.22 \mu \mathrm{m}) ; 6$, discharge port; 7,8 , inlet of compressed air.

\subsection{Preparation for coliphage}

Concentrations of infective coliphages were determined by the plaque forming unit (PFU) assay, using the double agar overlay (DAL) method. Coliphages T4 and host bacteria $(E$. coli $\mathrm{B})$ were purchased from Wuhan Institute of Virology, Chinese Academy of Sciences. Coliphages $\mathrm{f} 2$ and host bacteria (E. coli 285) were purchased from Institute of Hygiene and Environmental Medicine, Academy of Military Medical Sciences.

The culture media for $E$. coli $\mathrm{B} / E$. coli 285 were composed of the following: peptone $10 \mathrm{~g} / \mathrm{L}$, beef extract 3 $\mathrm{g} / \mathrm{L}$, sodium chloride $5 \mathrm{~g} / \mathrm{L}, \mathrm{pH}$ 7.0. The top layer of soft agar and the bottom rigid layer, respectively, contained

Table 1 Shape, size, and nucleic acid type of some viruses

\begin{tabular}{|c|c|c|c|}
\hline Model virus & Size & Genome & Shape \\
\hline Adenovirus & $65-85 \mathrm{~nm}$ & dsDNA & Angular head, no tail \\
\hline $\mathrm{T} 4$ & $65 \mathrm{~nm} \times 95 \mathrm{~nm}$ (body), $25 \mathrm{~nm} \times 110 \mathrm{~nm}$ (tail) & dsDNA & Angular head, contractile tail \\
\hline Poliovirus & $27-30 \mathrm{~nm}$ & ssRNA & Icosohedron \\
\hline Hepatitis A virus & $28-30 \mathrm{~nm}$ & ssRNA & Icosohedron \\
\hline $\mathrm{f} 2$ & $24-26 \mathrm{~nm}$ & ssRNA & Icosohedron \\
\hline
\end{tabular}


agar of 8 and $15 \mathrm{~g} / \mathrm{L}$. The media were autoclaved at $121^{\circ} \mathrm{C}$ for $20 \mathrm{~min}$ before use. The preparation for coliphages was as follows: a loop of coliphage T4/f2 was seeded in a flask containing a culture medium of $E$. coli $\mathrm{B} / E$. coli 285 which had been incubated at $37^{\circ} \mathrm{C}$ for $12 \mathrm{~h}$ to ensure growth of the bacterium. The flask was then continuously shaken at $37^{\circ} \mathrm{C}$ for another few hours to complete cell lysis. Thereafter, the flask was supplied with some culture media which had been incubated for 6 h to obtain young $E$. coli $\mathrm{B} / E$. coli 285 cells so as to enhance the titer of the coliphages, and was then shaken until another complete lysis was completed. The lysate was collected and centrifuged at $2500 \mathrm{r} / \mathrm{min}$ for $10 \mathrm{~min}$. The supernatant was added to sewage water to make the coliphage concentration in a range from $10^{5}$ to $10^{8} \mathrm{PFU}$ $/ \mathrm{mL}$.

The $\mathrm{T} 4$ atomic force microscope image was taken by NanoScope IIIa Multimode Scanning Probe Microscopy Instruments (Digital Instruments, Santa Barbara, CA, USA). According to the image, its average size is about $107.9 \pm 12.9 \mathrm{~nm}$. The surfaces of the new membrane of PP and PVDF were viewed under a scanning electron microscope (Fei Quanta 200, Holand).

\subsection{Evaluation of retention data}

The influent, supernatant liquid and effluent samples were taken periodically. The supernatant was obtained by centrifuging mixed liquor from the MBR at 4000 $\mathrm{r} / \mathrm{min}$ for $10 \mathrm{~min}$ in order to remove suspended solids. The retention of coliphage was calculated with eqs. (1) and (2), which gives the lg reduction value (LRV):

$$
\begin{gathered}
\mathrm{LRV}_{\mathrm{MBR}}=\lg c_{\text {in }} / c_{\text {out }}, \\
\mathrm{LRV}_{\text {mem }}=\lg c_{\text {super }} / c_{\text {out }},
\end{gathered}
$$

where $\mathrm{LRV}_{\mathrm{MBR}}$ is total removal by MBR system, $\mathrm{LRV}_{\text {mem }}$ is log microbial rejection by the membrane, and $c_{\text {in }}, c_{\text {super }}$ and $c_{\text {out }}$ are the coliphage concentrations in influent, supernatant liquid and effluent, respectively.

\subsection{Extract coliphage from activated sludge}

Desorption of coliphages from activated sludge samples was carried out as follows. The activated sludge samples were centrifuged at $5000 \mathrm{r} / \mathrm{min}$ for $15 \mathrm{~min}$. The supernatant was samples with non-adsorbed virus particles. The precipitate was rinsed three times by the EDTA-Gly buffer solution $(0.05 \mathrm{~mol} / \mathrm{L}$ EDTA, $0.25 \mathrm{~mol} / \mathrm{L}$ Gly, $\mathrm{pH}=9.5$ ). Extraction medium was added and the mixture was shaken gently at room temperature for $10 \mathrm{~min}$. It was confirmed separately that $10 \mathrm{~min}$ was long enough to reach the desorbed equilibrium. The adhered viruses on activated sludge samples were washed out by the procedure. The effluent was adjusted to $\mathrm{pH} 7.2$ and numbers of released viral particles were determined by the plaque assay.

\section{Results and discussion}

\subsection{Virus rejection in monoculture environment (in the tap water system)}

In order to investigate the effects of pore size of different membrane modules on the rejection of virus, the studies were conducted in a monoculture environment, which was operated in the tap water. Viruses T4, slightly larger than $100 \mathrm{~nm}$ in size $(107.9 \pm 12.9 \mathrm{~nm})$, were tested by PP membrane. As expected, viruses T4 were retained by the PP membrane to the limits of assay detection. Compared with complete rejection by PP membrane, $2.1 \mathrm{lg}$ rejection could be achieved by PVDF membrane with the mean pore sizes of $220 \mathrm{~nm}$. Although the diameter of viruses $\mathrm{f} 2(25 \pm 1 \mathrm{~nm})$ was significantly smaller than the membrane pores, it was found that $48 \%-70 \%(0.3-0.5 \mathrm{lg})$ of the influent virus was rejected in membrane separation processes. Table 2 described virus rejection by the two membrane modules during the trials.

\begin{tabular}{|c|c|c|c|c|}
\hline \multirow{2}{*}{$\begin{array}{c}\text { Virus } \\
\text { Membrane }\end{array}$} & \multicolumn{2}{|c|}{$\mathrm{T} 4$} & \multicolumn{2}{|c|}{$\mathrm{f} 2$} \\
\hline & PVDF (220 nm) & $\mathrm{PP}(100 \mathrm{~nm})$ & PVDF (220 nm) & $\mathrm{PP}(100 \mathrm{~nm})$ \\
\hline Supernatant concentration $(\mathrm{lg} \mathrm{PFU} / \mathrm{mL})$ & 5.8 & 5.8 & 5.0 & 5.0 \\
\hline Effluent concentration ( $1 \mathrm{~g} P F U / m L)$ & 3.7 & 0 & 4.7 & 4.5 \\
\hline LRV (lg PFU/mL) & 2.1 & 5.8 & 0.3 & 0.5 \\
\hline$\lambda=r_{\mathrm{s}} / r_{\mathrm{p}}$ & $0.49 \pm 0.06$ & $1.07 \pm 0.13$ & 0.11 & 0.25 \\
\hline Theoretic rejection $^{\mathrm{a})}(\%)$ & $54.5 \pm 8.5$ & $99.8 \pm 0.2$ & 4.6 & 19.1 \\
\hline Real rejection (\%) & 99.2 & 99.9998 & 48.6 & 70.2 \\
\hline
\end{tabular}

Table 2 Virus rejection by different membrane modules

a) Theoretic rejection referred to the value which was calculated by eq. (3) in the next. 
Generally, the mechanism of sieve retention attributed to particulate removal in membrane filtration. In sieve retention, the porous media acts as a barrier for particle penetration. The particles are retained on the membrane surface and form a cake that grows in thickness with the filtration. The removal of virus by membranes depends on many factors including membrane pore size, virus diameter, hydrophobic and electrostatic interactions. In previous researches ${ }^{[14-16]}$, the ratio of virus diameter to membrane pore diameter was the most critical parameter for the retention of viruses by microfiltration and ultrafiltration. According to the mechanism of sieve retention, the rejection, $R$, was calculated by the following expression ${ }^{[17]}$ :

$$
R=[\lambda(2-\lambda)]^{2}
$$

where $\lambda$ refers to the ratio of virus diameter and membrane pore size.

Table 2 shows that virus rejection results in the experiments were generally higher than theoretic values calculated eq. (3) with either T4 or f2. For example, the pore size of the PVDF membrane was approximately 2 times that of the diameter of virus T4. According to the prediction, about half of the viruses, particles would penetrate through the PVDF membrane. However, the virus rejection by PVDF membrane reached $99.2 \%$. The deviation between the real rejection and the prediction by the sieve theory could be partially explained by the size distribution of pore size and virus diameter. First, the virus size and membrane pore were not identical to the nominal sizes measured by the Atomic Force Microscope (AFM) and Scanning Electron microscope (SEM) observations. The particle sizes were not equal to the mean sizes measured by AFM observation (Figure

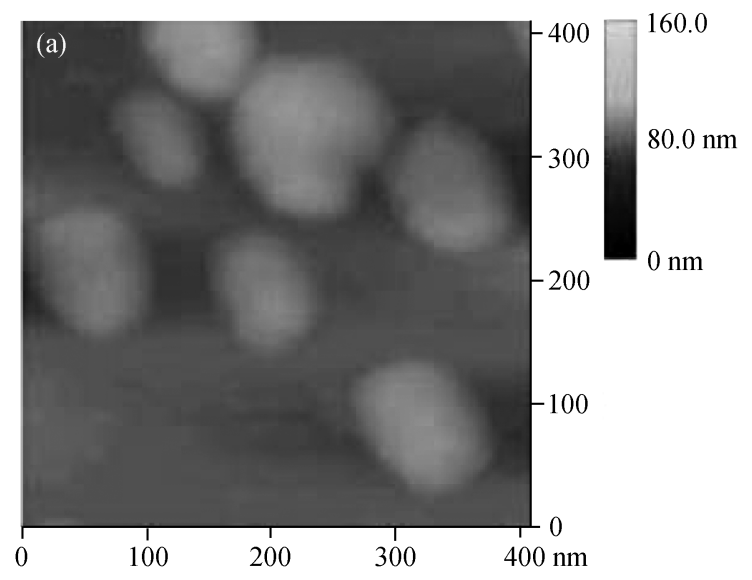

2(a)). The standard deviations of the sizes of the T4 particle were calculated to be $12.9 \mathrm{~nm}$. In addition, it is natural the membranes prepared by the phase inversion method have the lg-normal distribution of pore size. Membrane pore distributions, measured by SEM observation, were not identical to the nominal sizes (Figure 3(a)). Another possible explanation is aggregation of viruses with a high concentration. Viruses are considered as bio colloids with electrical properties governing their adsorption to biological and non-biological surfaces. Their surface electrical charges result from the ionization of carboxyl $\left(\mathrm{COO}^{-}\right)$and amino $\left(\mathrm{NH}_{3}^{+}\right)$groups localized on the surface of their protein coat. Viruses are released from infected host cells in a highly aggregated state and they probably kept the state when entering wastewaters and natural waters. Ionic conditions prevailing in natural waters do not lead to viral dispersion, and this association is due to Brownian motion, electrostatic forces, and electrical double-layer phenomena. The microorganisms' size becomes more and more large because of viral aggregates. Thus they may be rejected when they are larger than the membrane size. The aggregation of viruses was also confirmed by the measurements. It showed that the particle size of aggregation may be $2-3$ times greater than nominal virus size in Figure 2(b).

In addition, membrane structure is considered to be an important factor affecting virus transmission through the membrane. The cross section and inlet of PVDF are shown in Figure 3. Membrane structure of PVDF was asymmetric, and the pore structure was distributed unevenly via the cross section of the membrane. The asymmetric structure was effective to reject $\mathrm{T} 4$.

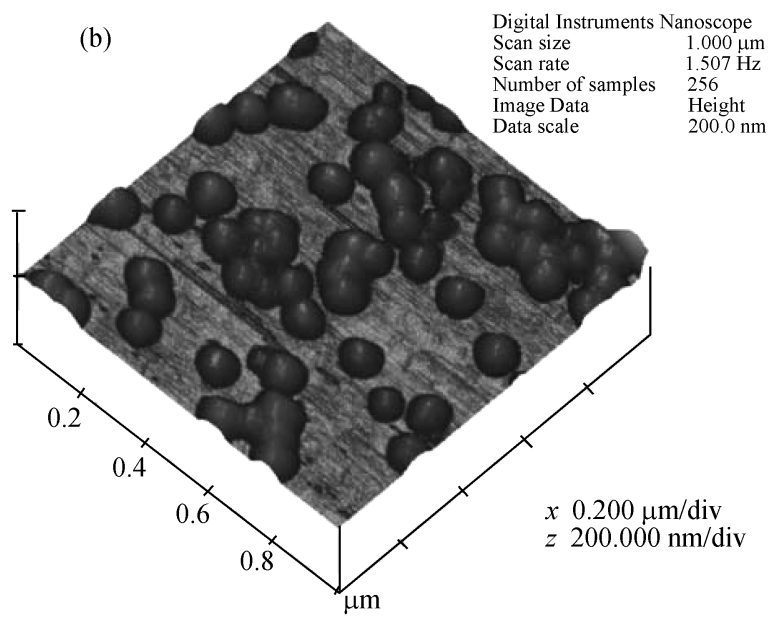

Figure 2 AFM image of the virus T4 used. (a) Low concentration; (b) high concentration. 

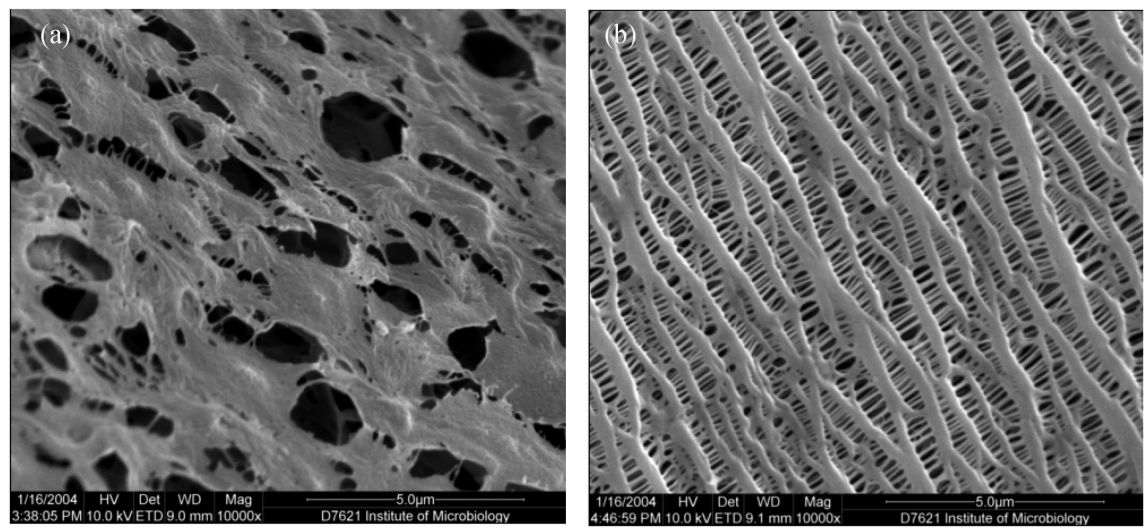

Figure 3 SEM Images of the new membrane surface. (a) PVDF $(\times 10000)$; (b) PP $(\times 10000)$

\subsection{Virus rejection in MBR (in the activated sludge system)}

Compared with mono-environment, the great difference for the membrane separation in the activated sludge process is that the retained components build up a layer on the membrane surface (dynamic membrane) during MBR operation. This dynamic membrane, including cake layer and gel layer, can affect or even change the initial characteristics of membrane, especially the cutoff. Virus T4 removal was investigated during the operation of the MBR (Figure 4). The influent virus concentration was in a range from $10^{5.8}$ to $10^{7.4} \mathrm{PFU} / \mathrm{mL}$. After $12 \mathrm{~h}$ operation, effluent virus concentration was $10 \mathrm{PFU} / \mathrm{mL}$. $5 \mathrm{~d}$ later, virus concentration decreased to $1-2 \mathrm{PFU} /$ $\mathrm{mL}$. There are only $50 \%$ of the samples of effluent, in which $1-2 \mathrm{PFU} / \mathrm{mL}$ viruses were detected during the continuous experiments. The PP membrane with smaller pore size has been used for the removal of viruses and high removal efficiencies have been achieved, and nearly no virus has been detected in the effluent. No significant difference was observed between both pore

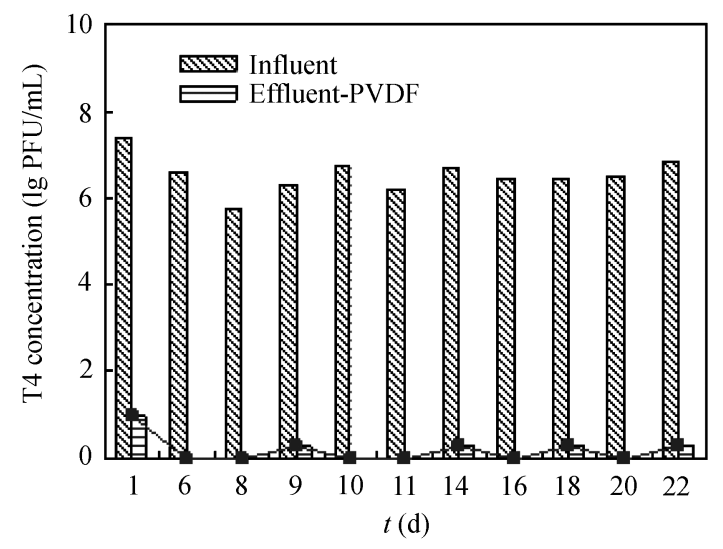

Figure 4 Virus T4 removal by PVDF membrane $(0.22 \mu \mathrm{m})$. sizes as the effluent virus concentration was in the same order. The removal ratios of coliphage $\mathrm{T} 4$ in the two membrane modules were higher than $5.5 \mathrm{lg}$ in both cases at steady state.

Variations of the influent, supernatant and effluent virus $\mathrm{f} 2$ concentrations are presented in Figure 5. During the experimental period, it is clear that accumulation of virus in the supernatant did not occur under the experimental conditions although $\mathrm{f} 2$ was continuously injected into the reactor. The initial rejection of $\mathrm{f} 2$ by the PVDF and PP membrane at time zero was about $0.3 \mathrm{lg}(48.6 \%)$ and $0.5 \mathrm{lg}(70.2 \%)$, respectively. When membrane resistance of PVDF increased from $5.2 \times 10^{-11}$ to $1.9 \times 10^{-12}$ after $18 \mathrm{~h}$ of membrane filtration, $\mathrm{LRV}_{\text {mem }}$ increased sharply from $0.3 \mathrm{lg}(48.6 \%)$ to $2.4 \mathrm{lg}(99.63 \%)$. At the same time, more than $2.1 \mathrm{lg}(99.14 \%)$ removal by PP membrane was observed in the second day. Compared with poor virus removal $(0.45 \pm 0.15 \mathrm{lg})$ in the tap water, the $\mathrm{LRV}_{\text {mem }}$ stabilized at about 3.0-4.0 lg removal after $6 \mathrm{~d}$ of operation either by PVDF or PP membrane. Variations of $\mathrm{LRV}_{\text {mem }}$ showed that the formation of a cake layer on the membrane surface resulted in higher

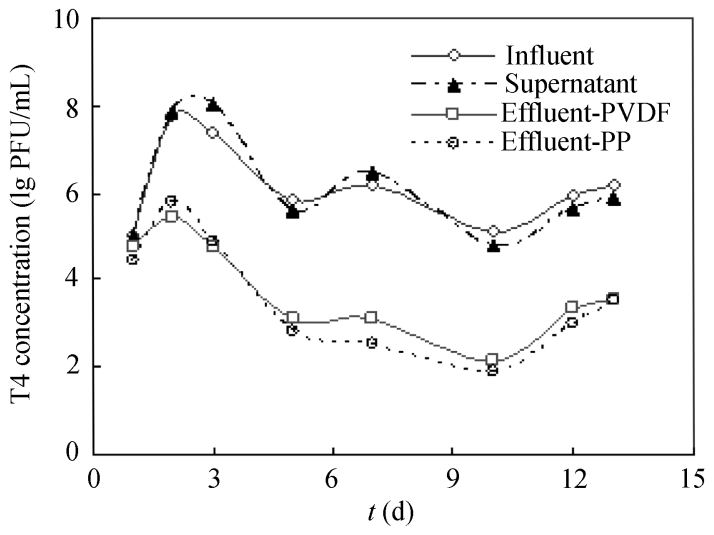

Figure 5 The virus $\mathrm{f} 2$ levels in the influent, supernatant and effluent. 
$\mathrm{LRV}_{\text {mem }}$ in a short time.

\subsection{Dynamic membrane for virus rejection}

Significant difference of virus rejection was observed between the tap water system and activated sludge system. In tap water, the membrane rejection was $2.1 \mathrm{lg}$ for T4. While in activated sludge system, the rejection was $5.8 \mathrm{lg}$. It means that virus rejection by new membrane depended on size sieving of the membrane pores at beginning of the operation, but after a few hours operation in the MBR the rejection mainly depended on the dynamic layer, not on membrane itself. Dynamic layer depositing on the membrane surface changed the cut-off size of the membrane into the smaller one. In general, the formation of the dynamic layer can be divided into the two stages: cake formation at the beginning of filtration and formation of gel layer with the proceeding of microfiltration operation. Extracellular polymeric substances (EPS) composed of many organic compounds, such as polysaccharides, amino polysaccharides and proteins, secreted by bacteria played an important role in the formation of gel layer and enhanced microbial attachment to membrane surface. In order to measure the contributions of cake layer and gel layer in the dynamic layer on the membrane surface separately, PVDF membrane was firstly washed by clean water to detach the cake layer on the membrane fibers, and then immersed in the chemical solutions $(0.7 \%$ sodium hydroxide and $2 \%$ sodium hypochlorite) to damage the EPS closely absorbed on the membrane fibers. After tap water cleaning, virus $\mathrm{T} 4$ concentrations of effluent increased from $0-2 \mathrm{PFU} / \mathrm{mL}$ to $400-500 \mathrm{PFU} / \mathrm{mL}$ in the tap water system, and accordingly membrane resistance decreased from 6.4 to $3.5 \times 10^{-12}$ (Table 3 ). The corresponding virus rejections decreased from $6.1 \mathrm{lg}$ to $2.8 \mathrm{lg}$, indicating that the contribution of cake layer's rejection was $3.3 \mathrm{lg}$.

After chemical cleaning, concentrations of $\mathrm{T} 4$ in the effluent increased to $2000-16000 \mathrm{PFU} / \mathrm{mL}$ in the tap water system. Since chemical cleaning caused a further reduction in the value of virus rejection, it could imply that the breakage of gel layer reduced the available membrane pore during microfiltration. Studies of relative contributions in virus removal confirmed that virus rejection by cake layer was the main cause of high removal rate of coliphage T4. Membrane itself was the next largest contributor. Virus rejection by gel layer contributed less than that by both cake layer and membrane itself in the presence of tap water (Table 3). These results proved that dynamic layer on membrane surface played an important role in removing virus. The formation of dynamic layer decreased the practical cut-off and thus prevented the filtration of virus. For PP membrane, there was no significant difference between tap water cleaning and chemical cleaning. These results proved that the small pore size was the main cause of high rejection of coliphage T4 for PP membrane (Table 4).

\subsection{Mechanism of virus removal in activated sludge system}

The conventional activated sludge process is an effective biological treatment in virus reduction. The removal of viruses is due to the adsorption to sludge solids and inactivation by microbial activity. Previous studies on vi-

Table 3 Virus T4 rejection by PVDF membrane ${ }^{\text {a) }}$

\begin{tabular}{|c|c|c|c|}
\hline System & Activated sludge system & Tap water system (clean water washing) & Tap water system (chemical cleaning) \\
\hline$R_{\mathrm{t}}$ & $R_{\mathrm{m}}+R_{\mathrm{g}}+R_{\mathrm{c}}$ & $R_{\mathrm{m}}+R_{\mathrm{g}}$ & $R_{\mathrm{m}}$ \\
\hline$R_{\mathrm{t}}$ & $6.4 \times 10^{-12}$ & $3.5 \times 10^{-12}$ & $1.5 \times 10^{-12}$ \\
\hline Supernatant concentration ( $\lg \mathrm{PFU} / \mathrm{mL})$ & $6.3 \pm 0.1$ & $5.5 \pm 0.4$ & $5.8 \pm 0.0$ \\
\hline Effluent concentration (lg PFU/mL) & $0.2 \pm 0.2$ & $2.7 \pm 0.0$ & $3.8 \pm 0.6$ \\
\hline LRV (lg PFU/mL) & $6.1 \pm 0.2$ & $2.8 \pm 0.4$ & $2.0 \pm 0.6$ \\
\hline
\end{tabular}

a) Total filtration resistance $\left(R_{\mathrm{t}}\right)$ consists of intrinsic membrane resistance $\left(R_{\mathrm{m}}\right)$, cake resistance $\left(R_{\mathrm{c}}\right)$ and gel resistance $\left(R_{\mathrm{g}}\right)$.

Table 4 Virus T4 rejection by PP membrane ${ }^{\text {a) }}$

\begin{tabular}{|c|c|c|c|}
\hline System & Activated sludge system & Tap water system (clean water washing) & Tap water system (chemical cleaning) \\
\hline$R_{\mathrm{t}}$ & $R_{\mathrm{m}}+R_{\mathrm{g}}+R_{\mathrm{c}}$ & $R_{\mathrm{m}}+R_{\mathrm{g}}$ & $R_{\mathrm{m}}$ \\
\hline$R_{\mathrm{t}}$ & $21.2 \times 10^{-12}$ & $9.1 \times 10^{-12}$ & $5.1 \times 10^{-12}$ \\
\hline Supernatant concentration ( $\lg \mathrm{PFU} / \mathrm{mL})$ & $6.3 \pm 0.1$ & $5.5 \pm 0.4$ & $5.8 \pm 0.0$ \\
\hline Effluent concentration (lg PFU/mL) & $0.0 \pm 0.0$ & $0.0 \pm 0.0$ & $0.3 \pm 0.0$ \\
\hline LRV (lg PFU/mL) & $6.3 \pm 0.1$ & $5.5 \pm 0.4$ & $5.5 \pm 0.6$ \\
\hline
\end{tabular}

a) Total filtration resistance $\left(R_{\mathrm{t}}\right)$ consists of intrinsic membrane resistance $\left(R_{\mathrm{m}}\right)$, cake resistance $\left(R_{\mathrm{c}}\right)$ and gel resistance $\left(R_{\mathrm{g}}\right)$. 
rus removal by activated sludge process suggested that adsorption of virus to wastewater particulates, which subsequently settle and become components of sludge, is the main mechanism of virus removal. Thus, the activated sludge process transfers viruses from wastewater to sludge, and most of the solid-associated viruses are infective. Further evidences that viruses are truly inactivated during this treatment process have been provided by more recent studies ${ }^{[18-20]}$.

Variations of virus $\mathrm{f} 2$ concentrations in the influent, supernatant and effluent are presented in Figure 5. During the experimental period, it was clear that accumulation of virus in the supernatant did not occur under the experimental conditions although $\mathrm{f} 2$ was continuously injected into the reactor. Adsorption and inactivation by activated sludge may lead to the removal of viruses in the supernatant. However, the role of the activated sludge on the virus inactivation remains unclear.

Particulate virus was retained by membrane within the bioreactor, which did not lose its infection. Therefore, membrane rejection only distributed virus between the effluent and the activated sludge mixed liquid in the bioreactor. In the closed system of MBR, adsorption onto the sludge and inactivation by the microbes could not be distinguished. However, virus removal can be calculated from the influent and the effluent virus concentration, including inactivation and adsorption in an open system like activated sludge system without membrane rejection.

Hence, in order to understand the relative contributions of adsorption to sludge solids and the inactivation by microbial activity in $\mathrm{T} 4$ removal, it is important to study the relation between adsorption and inactivation by the solid fraction of the mixed liquor. Viruses were recovered from solid matters by the EDTA-Gly buffer solution. The virus was also mainly detected in the solid

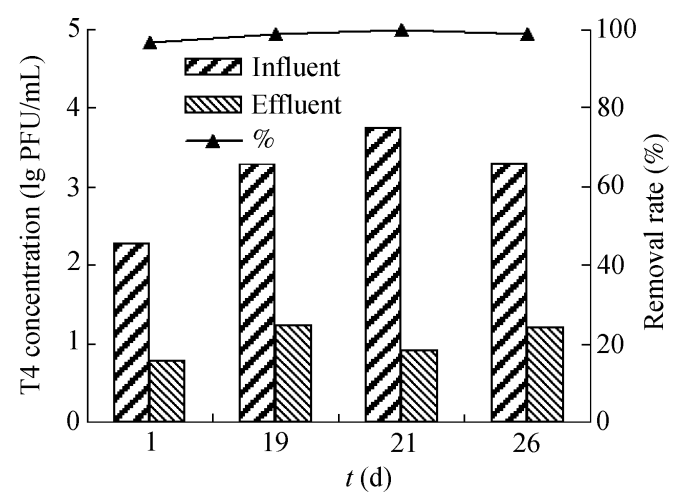

Figure 6 Virus T4 removal in activated sludge system. fractions of the mixed liquor compared with the supernatant. The viral concentration of effluent remained fairly stable $(58-160 \mathrm{PFU} / \mathrm{mL})$ throughout the 28-day sampling period when the virus concentration of influent fluctuated from 1830 to $57000 \mathrm{PFU} / \mathrm{mL}$ (Figure 6). Figure 7 shows the contribution of adsorption and inactivation to the overall virus removal which was estimated separately by activated sludge process. Only $0.8 \%-$ $22 \%$ virus removal was observed by the adsorption of activated sludge, while virus inactivation by microbial activity reached $75 \%-98 \%$. Adsorption by activated sludge contributed to virus removal less than $22 \%$ of the total removal, and the decreasing tendency of adsorption was observed in the continue experiment. It indicated that the main mechanism of virus removal was not the transfer of viruses from the water phase to the sludge phase but inactivation.

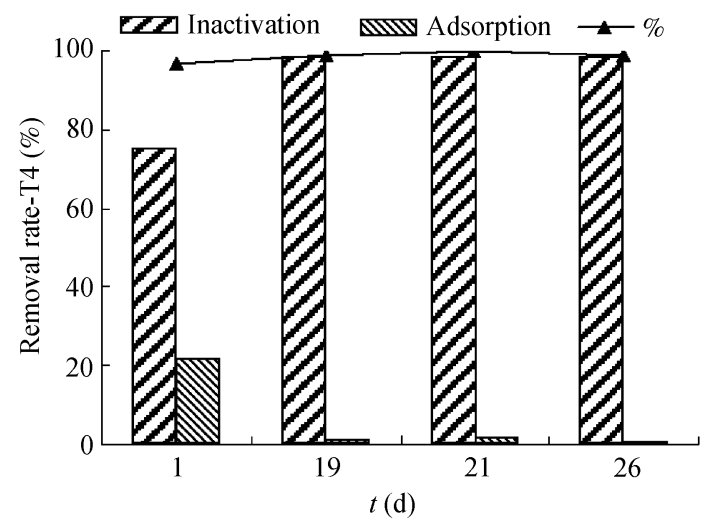

Figure 7 Removal mechanism of virus T4 in activated sludge system.

\section{Conclusions}

(1) In tap water system, membranes were highly effective in removing virus $\mathrm{T} 4$ and $\mathrm{f} 2$ and such effect of virus rejection was closely related to the membrane pore size.

(2) In MBR, the different membrane pore sizes had no significant effect on the virus rejection for the cake layer and gel layer on the membrane surface play an important role.

(3) In conventional activated sludge system, the virus removal depended more on the inactivation by microbial activity than the adsorption to the sludge since the contribution of adsorption showed the decline with the retention time.

The authors would like to thank Mr. ZHU Hui and Dr ZENG ping for help in the paper reviewing. The support of ZHANG Kai, JIANG Daqian, YE Lei and HE Ming for assistance in the virus assays and general support is also kindly acknowledged. 
1 Wei D B, Hu H Y, Wang L S. Sanitary system of in reused wastewater. China Water \& Wastewater (in Chinese), 2004, 20(1): 36-39

2 Qiu F G, Wang X C, Assessment on health effects of viruses in reused wastewater in city. J Environ Health (in Chinese), 2003, 20(4): 197-199

3 Zheng X, Lv W Z, Yang M, Liu J X. Evaluation of virus removal in MBR using coliphages T4. Chin Sci Bull, 2005, 50(9): 862 - 867

4 Lv W Z, Zheng X, Yang M, Liu J X. Removal efficiency of viruses in simulated hospital wastewater by using a submerged membrane bioreactor. Process Biochemistry, 2006, 41: 299-304

5 Gunder B, Krauth K. Replacement of secondary clarification by membrane separation-results with plate and hollow fibre modules. Wat Sci Tech, 1998, 38(4-5): 383-393

6 Steven W T, Simon J J, Bob M. Reduction of faecal coliform bacteria in sewage effluents using a microporous polymeric membrane. Water Res, 1998, 32(5): 1417-1422

7 Krauth K, Staab K F. Pressurized bioreactor with membrane separation for wastewater treatment. Water Res, 1993, 27(3): 405-411

8 Zheng X, Liu J X. Mechanism investigation of virus removal in a membrane bioreactor. Wat Sci Tech; Wat Supp, 2006, 6(6): 51-59

9 Ueda T, Horan N J, Fate of indigenous bacteriophage in a membrane bioreactor. Water Res, 2000, 34(7): 2151-2159

10 Shang C, Wong H M, Chen G H. Bacteriophage MS-2 removal by submerged membrane bioreactor. Water Res, 2005, 39: 4211-4219
11 Britton G. Introduction to Environmental Virology. New York: John Wiley \& Sons, Inc,1980. 300-317

12 Berg G. Viral Pollution of the Environment. Boca Raton: CRC Press, Inc, 1983. 141- 145

13 Li M, Hu H Y. Revieww of bacteriophages as viral indicators in water. China Water \& Wastewater, 2005. 21(2): 23-26

14 Urase T, Yamamoto K, Shinichiro O. Effect of pore size distribution of ultrafiltration membranes on virus rejection in crossflow conditions. Wat Sci Tech, 1994, 30(9): 199-208

15 Madaeni S S. The application of membrane technology for water disinfection. Water Res, 1999, 33(2): 301-308

16 Herath G, Yamamoto K, Urase T. Mechanism of bacterial and virus transport through microfiltration membranes. Wat Sci Tech, 1998, 38(4-5): 489-496

17 Shi J, Yuan Q, Gao C J. Handbook of Membrane Technology. Beijing: Chemical Industry Press, 2001. 337-339

18 Richard L W. Evidence that microorganisms cause inactivation of viruses in activated sludge. Appl Environ Microbiol, 1982, 43(5): $1121-1124$

19 Nasser A M, Glozman R, Nitzan Y. Contribution of microbial activity to virus reduction in saturated soil. Water Res, 2002, 36: 2589-2595

20 Kim T D, Unno H. The roles of microbes in the removal and inactivation of viruses in a biological wastewater treatment system. Wat Sci Tech, 1996, 33(10-11): 243-250 